\title{
The Effectiveness Of Local Culture-Based Video In Improving Listening Ability Of French Students Unimed
}

\author{
Nurilam Harianja ${ }^{1 *}$, Hesti Fibriasari ${ }^{2}$, T. Ratna Soraya ${ }^{3}$ \\ ${ }^{1,2,3}$ Universitas negeri Medan, Indonesia \\ *nurilam@unimed.ac.id ${ }^{1}$
}

\begin{abstract}
This research aims to obtain data on the effectiveness of local culture-based learning video in improving the listening ability of Unimed students. The method used in this research is an experimental study using the Pre Test - Post Test questions. This research used two classes, namely the experimental class that used local culture-based video and the control class that did not used local culture-based video. The sample in this research is 23 students in experimental class. The result of the study is concluded that the control class had an average pre-test score of $66 \%$ and an average post-test score of $70 \%$, compared to the experimental class which had an average pre-test score of $60 \%$ and an average post-test score of $78 \%$ after receiving treatment that is by using local culturebased video. These results indicate that the average post test score in the experimental class is higher because it increased as $18 \%$ while the control class has increased by only $4 \%$. The conclusion is learning media of local culture-based video is more effective used on Reception Orale course.
\end{abstract}

Key words: video learning media, local culture, reception orale

\section{Introduction}

Learning language from the secondary school level or at the university level is expected not only to master language skills but also to help students getting to know themselves, their culture and other culture. The influence of technological progress on the development of education in Indonesia is very big so that educational institutions try to support the learning process by using existing technology. The use of media is one of the supporting in the learning process. Arsyad [1] said that the media is an inseparable part of the teaching and learning process for the achievement of educational goals. Learning video media is an assisting tool in the delivery of material to support the learning process in order to achieve active learning. Presentation of information through this media is in the form of a living document, can be seen through the monitor screen and can be seen its moving and heard its sounds and movements. The media aims to present information in a form which is fun, interesting, easy to understand and clear, information will be easy to be understood because as many senses as possible, especially the ears and eyes, are used to absorb that information [1].

This research uses learning media local culture-based video with La Famille, faire des achats, and presentation materials. Learning media Local culture-based video is expected to be able to improve students' ability in listening competency in French. According to an education expert, Sinaga [2] said that culture-based education is one of the learning strategies 
that needs to be developed in schools because it is considered to be able to motivate learners to learn more actively to provide positive values for them. This is based on person's way of thinking, perceiving and acts are influenced by the culture, environment and others around him. The cultural approach can increase interest in learning because students can more easily understand the material sourced from their own culture. Referring to the explanation above, the researcher integrates local culture into the video that will be used as a medium for learning Reception Orale in French.

\section{Research Method}

This research is a type of quantitative research with experimental methods where the regular class A 2019 as the experimental class and the regular B 2019 as the control class. Learning media local culture-based video is used in the experimental class while in control class uses video that is not based on local culture [3]. Data collection techniques used in the research of the effectiveness of the media use of local culture-based video are:

The test is carried out to measure basic skills and achievement in Reception Orale course with presentation material by using learning media, which are local culture-based videos. Tests and questions in the form of multiple choices are used to measure initial knowledge through pre-test and post-test to determine the final results after students are treated using local culture-based videos and then with control class that use learning media in the form of videos that are not based on local culture [4].

Documentation is a data collection technique in the form of photos and information taken during the research process to strengthen the data obtained by researchers while in the field [5]. Observation is carried out to determine the learning process by using learning media in the form of local culture-based videos with presentation material in experimental class [6]

\section{Result and Discussion}

Learning Outcome in Control Class

The recapitulation result obtained from B 2019 regular students were made into the control class with an average pre-test score of $66 \%$ and an average post-test score of $70 \%$, the results indicate that there was an increase of $4 \%$ using learning media local culture-non-based video.

Learning Outcome in Experimental Class

Based on the recapitulation of the pre-test and post-test average score in Regular class A 2019 that was used as the experimental class showed that there was an increase of $18 \%$. In the pre-test the average score was only $60 \%$ and in the post-test it became $78 \%$. This increase shows that the experimental class increased more than the control class that increased $4 \%$. In conclusion, local culture-based videos are more effective for increasing the listening ability to French students.

Comparison between Experiment and Control Class

Based on the results of the data obtained from the control class and the experimental class, it is known the comparison between learning outcomes of regular students 2019 on the 
presentation material. From both classes, the results of the Man-Whitney Whitney test are obtained significance level $0.002<0.05$ means that the significance score is less than 0.05 then $\mathrm{H} 0$ is rejected, so there is a significant difference between the pre-test on control class and the pre-test on experimental class, and when the statistical test uses Mann Whitney in the post-test of the control class and the experimental obtained significance score of $0,000<0.05$. Because the significance level is less than 0.05 then Ho is rejected, the conclusion is that there is a significant difference between the post-test on control class and the post-test on experimental class. While the result of calculation using the Wilxocon test mentioned $\mathrm{x}$ that significant score of p-value $0,000<0.05$ then Ho was rejected. The conclusion was that there was a significant difference of score between the pre-test on experimental class and post-test on experimental class.

The result of an increase in the experimental class from $60 \%$ to $78 \%$ means an increase as $18 \%$, while the control class from $65 \%$ to $70 \%$ an increase as $4 \%$. In conclusion, using local culture-based video media is more effective and can increase students' success in learning process compared to local culture-non-based video media, this is evidenced from the increase of average scores in the experimental and control classes.

\section{Conclusion}

Based on the results of data analysis and discussion that has been described then conclusions can be drawn:

1) Learning objectives in the Reception Orale course on presentation material in the experimental class by using learning media in the form of local culture-based videos can be achieved with an increase of learning outcomes by $18 \%$. The results before the use of local culture-based video media were carried out (pre-test) by $60 \%$, increasing to $78 \%$ results after the implementation of local culture-based video media in the experimental class (post-test).

2) The results of the assessment from two classes show that the use of local culturebased video media with presentation material is more effective than using videos that are not based on local culture, as evidenced when the teaching and learning process in the classroom using local culture-based video media is easier for students to understand the contents of the video because it is motivated by their own culture.

\section{References}

[1] Arsyad Azhar. Media Pembelajaran. Jakarta : PT RajaGrafindo Persada. (2014).

[2] Sinaga, B. Pembelajaran berbasis budaya perlu dikembangkan dalam pendidikan. (2010)

[3] Sugiyono. Pendekatan Kualitatif, Kuantitatif dan R\&D. Bandung: Alfabeta. (2011).

[4] Fibriasari, H. Prosodic Frequency in Signaling Linguistic Distinctions at UNIMED First Year Non-native French Students. International Journal of Humanities and Social Science Vol. 6, No. 10; October 2016. Hal 118-124. (2016).

[5] Harianja, N. Youtube as the Learning Media to Improve the Speaking Skill in Expression Orale Course. Asian Themes in Social Sciences Research ISSN: 2578- 5516 Vol. 3, No. 1, pp. 14-17 2019 DOI: 10.33094/journal.139.2019.31.14.17. (2019). 